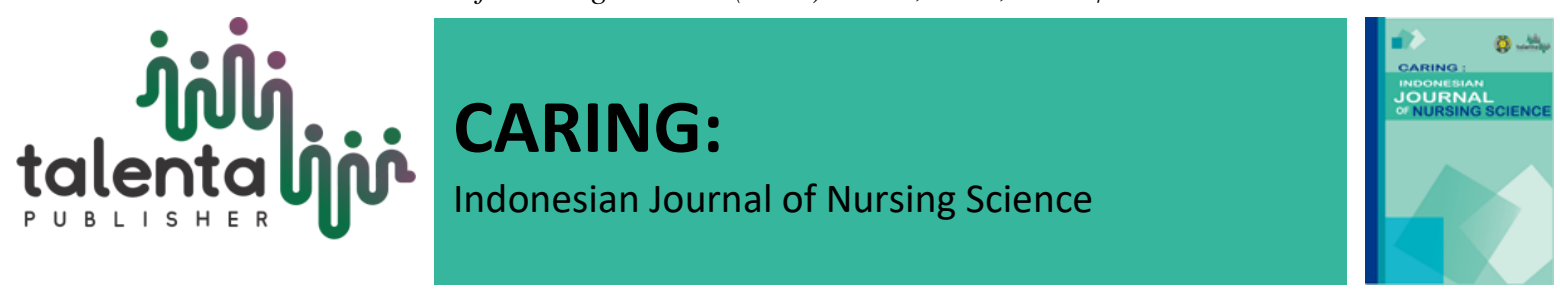

\title{
Community Behavior on Reproductive Health in Medan Johor, Indonesia
}

\author{
Siti Saidah Nasution, Ellyta Aijar, Rika Eliana
}

Faculty of Nursing, Universitas Sumatera Utara, Medan-Indonesia

\begin{abstract}
The aim of the health promotion is to increase awareness and the individual willingness to have a healthy life for everyone to achieve an optimal degree of public health. The government's programs in improving positive behavior and reproductive health in the community, especially maternal and infant health, is one of the priorities. Current health problems are focused on the high rates of maternal and infant mortality. This is related to the lack of preparation for couples before marriage and family such as early marriage. The government's initiative to declare pre-marriage as a condition for marriage in 2020 must be socialized and supported by all parties. This research is a descriptive study that aims to describe people's behavior about reproductive health, especially the knowledge and attitudes of adolescents. youths and girls about reproductive health in Medan Johor District. The population is all young people and girls in the Medan Johor sub-district. The sample of teenagers and young people gathered in the Karang Taruna Medan Johor region. Data collection using a questionnaire, which consists of demographic data, knowledge data, and attitudes related to reproductive health. Univariate data analysis used distribution and presentation frequency. The results of the research on knowledge of youth and girls about reproductive health are generally in the low category, namely around $56.4 \%$. The negative attitude is around $62.2 \%$. Health workers must be able to optimize their role in providing health education to the public, especially about reproductive health.
\end{abstract}

Keyword: Reproductive Health, Knowledge, Attitudes.

Received 22 September 2020 | Revised 13 December 2020 | Accepted 30 December 2020

\section{Introduction}

Community behavior in reproductive health is closely related to care starting from pregnancy, childbirth, childbirth, and newborns (Nasution. SS, et. al 2015). About the behavior of factors that can affect public health status, it is inseparable from the culture and habits of the family and the daily environment of society (Koentjaraningrat, 2009). Cultural values are concepts about something that exists in the minds of most of the people that they consider valuable, valuable, and important in life so that they can function as a guide that provides direction and orientation to the lives of community members (Sarwono, Sarlito. 2012). Currently, health problems in Indonesia are dominated by the low level of health of pregnant women, childbirth, and infant and child mortality, so that government programs prioritize accelerating the reduction of MMR

*Corresponding author at: Jl. Prof. Maas no. 3 Kampus USU Medan

Corresponding email: siti.saidah@usu.ac.id

Copyright (C) Published by Talenta Publisher, ISSN: 2580-6769 e-ISSN: 2580-829X

Journal Homepage: https://talenta.usu.ac.id/IJNS 
and IMR. Nationally, MMR and IMR in Indonesia are still high and cause for concern when compared to other countries. The current MMR is around 307 per 100,000 KH and the IMR 34 per $1,000 \mathrm{KH}$ [5]. The high rate of maternal and infant mortality cannot be separated from the role of the family in society. Lack of preparation for couples before marriage and family, both physically and psychologically, often occurs in couples with early marriage (Sarwono, Sarlito. 2012. Andrew E. Czeizel, Attila Vereczkey. (2012).

Incidents with household problems in the Medan Johor area are still found and according to village and Public health center officials are increasing, such as domestic violence, divorce, youth marriage, and increasing rates of abortion.

If we look further, the causes of maternal and infant mortality are closely related to daily behavior and care, both carried out by health workers in health services and family care (Andrew E. Czeizel, Attila Vereczkey, 2012). This is following the opinion that the baby's health status will be determined by the mother's health status at the time of pregnancy. Various diseases and problems that cause morbidity and mortality in mothers and babies are related to perceptions and culture which result in high risks in the health sector, these are still widely found in various places in Indonesia, especially in areas that are thick with customs (Nasution. SS, et. al 2015). The health condition of mothers and babies is an important indicator of national health. This is related to various factors including maternal health, quality, and access to medical services (Nasution. SS, (2018). The availability of various health facilities and services, the willingness of the community to change behavior that is detrimental to health is influenced by traditional norms to the norms of modern life, are important factors in improving health status (Natalie Hemsing, Lorraine Greaves, Nancy Poole. (2017).

Research in Nepal states that maternal mortality rates generally occur in pregnant women with no ANC examinations. The results of this study also explain that socio-economic conditions, including poverty, affect maternal and infant mortality rates associated with pregnancy and childbirth (Simkhada. B, Porter.M, Teijlingen.E. 2010). Another factor that contributes to the high mortality of mothers and babies is the lack of utilization of health services, low public access, and knowledge, especially in life that follows family traditions/habits from generation to generation. Infection and bleeding cases are the major causes of maternal and neonatal mortality associated with early pregnancy and childbirth (Corin, SS, Arnold, J. (2006). Nasution. SS, Badaruddin, Dasatjipta, G, Lubis. Z. (2015).

There has been an increase in cases of reproductive health in the Medan Johor, such as domestic violence, divorce, youth marriage, abortion, and pregnancy bleeding (Nasution. SS, Badaruddin, Dasatjipta, G, Lubis. Z. 2015). Unemployment and inadequate family economic conditions might induce psychological problems and affect reproductive health problems (Nasution. SS, Erniyati, Hariati (2019). The government programs giving awareness with health education related to reproductive health (Hamilton, PM, 2001), collaborate with the local government, village officials, health workers (Bobak, IM, Lowdermilk, DL, \& Jensen, MD 2005). Humphreys, J., \& Campbell, JC (2004). 


\section{Research Method}

This study is a quantitative study aims to determine the behavior of the community in Medan Johor for knowledge and attitudes toward reproductive health. The population is 712 people, with 156 people involved as the research sample with some criterias; Medan Johor youths and girls who are members of the Medan Johor Youth Organization and willing to participate. The sampling is quota random sampling. The study was conducted from April to September 2020. Data was collected using a questionnaire consisting of 3 parts; demographic data, knowledge, and attitudes. The data was processed in descriptive analysis, using the computer-based statistical software with percentage and frequency distribution.

\section{Result and Discussion}

The characteristics of the respondent's data describe the majority of the ages at high risk in reproductive health, namely around 20 years $(54.5 \%)$, female sex (55.1\%), middle-high school education (73\%), not working $84.6 \%$ ), Batak tribe (57.7\%), Characteristics can be seen in the table as followed:

Table1. Frequency distribution and percentage of respondent characteristics $(n=156)$

\begin{tabular}{|c|c|c|c|}
\hline No. & Respondent Characteristics & (f) & $(\%)$ \\
\hline 1. & $\begin{array}{l}\text { Age } \\
\text { a. }<20 \\
\text { b. } 21-35 \\
\text { c. }>35\end{array}$ & $\begin{array}{l}85 \\
61 \\
10\end{array}$ & $\begin{array}{r}54.5 \\
39.1 \\
6.4\end{array}$ \\
\hline 2. & $\begin{array}{l}\text { Sex } \\
\text { a. Male } \\
\text { b. Female }\end{array}$ & $\begin{array}{l}70 \\
86 \\
\end{array}$ & $\begin{array}{l}44.9 \\
55.1 \\
\end{array}$ \\
\hline 3. & $\begin{array}{l}\text { Level of Education } \\
\text { a. Primary } \\
\text { b. Secondary high school } \\
\text { c. College }\end{array}$ & $\begin{array}{c}12 \\
114 \\
30 \\
\end{array}$ & $\begin{array}{c}7,8 \\
73 \\
19.2 \\
\end{array}$ \\
\hline 4. & $\begin{array}{l}\text { Type of Work } \\
\text { a. Work (entrepreneur) } \\
\text { b. Unemployed }\end{array}$ & $\begin{array}{c}24 \\
132\end{array}$ & $\begin{array}{l}15.4 \\
84.6\end{array}$ \\
\hline 5. & $\begin{array}{l}\text { Ethnic Group } \\
\text { a. Batak } \\
\text { b. Java } \\
\text { c. Padang } \\
\text { d. Malay } \\
\text { e. Nias }\end{array}$ & $\begin{array}{l}90 \\
36 \\
10 \\
17 \\
3\end{array}$ & $\begin{array}{c}57.7 \\
23 \\
6.4 \\
10.9 \\
1.9\end{array}$ \\
\hline 6. & $\begin{array}{l}\text { Family Income } \\
\text { a. Following the UMR (IDR 3,222 } \\
\text { million) } \\
\text { b. <UMR } \\
\text { c. > UMR }\end{array}$ & $\begin{array}{l}73 \\
55 \\
28\end{array}$ & $\begin{array}{l}46.8 \\
35.3 \\
17.9\end{array}$ \\
\hline 7. & $\begin{array}{l}\text { Home status } \\
\text { a. Private House } \\
\text { b. Rent House }\end{array}$ & $\begin{array}{c}102 \\
54 \\
\end{array}$ & $\begin{array}{l}65.4 \\
34.6 \\
\end{array}$ \\
\hline \multicolumn{2}{|c|}{ Total } & 156 & 100 \\
\hline
\end{tabular}


The knowledge of youth and young women about reproductive health in the Medan Johor region can be described in the table as followed:

Table 2. Frequency distribution of knowledge about reproductive level $(n=156)$

\begin{tabular}{l|c|c}
\hline Knowledge & (f) & $(\mathbf{\% )}$ \\
\hline High & 22 & 14.1 \\
\hline Moderate & 46 & 29.5 \\
\hline Low & 88 & 56.4 \\
\hline Total & 156 & 100 \\
\hline
\end{tabular}

Based on the table above, the knowledge of young people in the Medan Johor community about reproductive health is generally in the low category, around $56.4 \%$.

In addition, the public attitudes about reproductive health is described in the table as followed:

Table 3. Frequency distribution of attitudes about reproductive level $(\mathrm{N}=156)$

\begin{tabular}{l|l|l}
\hline \multicolumn{1}{c|}{ Attitude } & \multicolumn{1}{|c|}{$(\mathbf{f})$} & \multicolumn{1}{c}{$(\boldsymbol{\%})$} \\
\hline Positive & 59 & 37.8 \\
\hline Negative & 97 & 62.2 \\
\hline Total & 156 & 100 \\
\hline
\end{tabular}

In general, attitudes are a negative attitude, which is around $62.2 \%$.

Reproductive health in adolescents, both young people and young women is an important starting point in the development of a quality young generation (Green, L., Wand Kreuter MW, 2005). Reproductive health is closely related to behavior/perceptions before marriage (Sarwono, Sarlito. 2012). Handling reproductive health problems requires the role of health workers including government officials through village officials and youth or youth and girl associations (Karang Taruna) in the sub-district. Medan Johor sub-district has a generation of adolescents with various age groups who are still heading towards their productive age. The results of the study, in general, the knowledge and attitudes of the community, especially young people and girls about reproductive health in the Medan Johor region are still in the low category and negative attitudes. Based on this, it is necessary to provide counseling and information about reproductive health. The role of health workers and village officials, especially the Karang Taruna group and health cadres, is very important in providing information to increase knowledge and attitudes (Notoatmodjo, S. 2007). One of the ways to overcome this problem is the Pre-Marriage Program as a means of being able to communicate early with the prospective bride and groom, especially young men and women to ensure that they are ready to marry and have to undergo several examinations called "Bride Candidate Counseling" (K- Catin). This program consists of physical health examinations related to reproduction (fertility) and genetics (heredity) then continued health checks in the laboratory, namely blood, blood and rhesus tests, blood sugar levels, urine, sexually transmitted disease detection, hepatitis B detection, and detection. diseases that cause abnormalities during pregnancy such as (TORCH), (May, KA \& Mahlmeister, LR 1994). Counseling is carried out by giving various materials and reproductive health sciences such as reproductive organs for women and men, the process of pregnancy, childbirth, postpartum and health care methods, mental/psychological preparation, preparation 
for social and family life, spiritual and economic readiness. In addition to counseling in the community and medical examinations, leaflets and modules were made, the formation of a counseling team, determined a place for counseling (Corin, SS, Arnold, J. 2006).

Before carrying out counseling, the education of young people and girls should be studied because education is closely related to understanding and attitudes in receiving health information (Notoatmodjo, S. 2007). This is following the concept which explains the factors that influence health behavior, one of which is the level of education (Nasution. SS, Erniyati, Hariati, 2019). Medan Johor consists of several neighborhoods with a varied population and around $70 \%$ are of productive age. The high cases of maternal and infant mortality are one of the effects of an unhealthy marriage both physically and psychologically (Sarwono, Sarlito. 2012). Incidents with domestic problems in the Medan Johor area are still found and according to village officials/officials, several social cases are increasing, such as domestic violence (KDRT), divorce, marriage at a young age, and increasing rates of abortion/miscarriage. This problem is related to a person's lack of preparation for marriage and immature physical and psychological conditions as a whole. Abusing crimes or psychological crimes that do not appear to be many potential candidates for divorce in Indonesia are high. Data from the Supreme Court in 2018 shows that nearly 419,268 couples divorced and had an impact on the psychological and health of family members, especially mothers and children. The importance of providing information about reproductive health before marriage is one solution in overcoming problems in the family (Humphreys, J., \& Campbell, JC 2004). Prospective parents, especially mothers as child caregivers, will be influenced by their education and knowledge of health. This is under the theory which states that knowledge can improve emotional control, increase client independence, increase self-esteem, increase endurance, and can help clients to adapt to problems or diseases which in turn can improve health status (Ministry of Health of the Republic of Indonesia, 2012). Knowledge and attitudes will relate to education, work, and individual experience in solving family problems. A mother-to-be or future father who knows with a positive attitude about health, especially reproductive health, will try to meet family needs and carry out proper care (Andrew E. Czeizel, Attila Vereczkey. (2012). This is by the opinion that age can affect a person's knowledge because the older a person is, there will be changes in the psychological (mental) aspect. On a psychological or mental aspect, a person's thinking level is more mature (Nasution. SS, Badaruddin, Dasatjipta, G, Lubis. Z. (2015). Knowledge is also influenced by the experience of the respondent. This is by the opinion that a person's knowledge tendency will be better with more experience than with less experience. External factors are the dominant factors in influencing knowledge, one of which is: access to information (Ministry of Health of the Republic of Indonesia, 2012) This is following the opinion that a person's knowledge tends to be better with more experience than with less experience. External factors are the dominant factors in influencing knowledge, one of which is: access to information (Notoatmodjo, S. 2007). This is under the opinion that a person's knowledge tendency will be better with more experience than with less experience. External 
factors are the dominant factors in influencing knowledge, one of which is: access to information (Nasution. SS, Badaruddin, Dasatjipta, G, Lubis.Z. 2015).

The factors that influence a person's perception are the person's self or the knowledge they have, the target perception, and the situation factors. The person's factor or the knowledge they have, that is, when someone sees something and tries to give his interpretation of what he sees, he is influenced by individual characteristics and knowledge that also influences such as attitudes, motives, interests, experiences, and expectations (Natalie Hemsing, Lorraine Greaves, Nancy Poole. 2017). Attitudes can be positive, namely, there is a tendency for actions to approach, like, and expect certain objects so that they are applied in the form of actions. Attitudes can be negative, namely the tendency to avoid, stay away from, and not trust or believe in certain objects. (Ministry of Health of the Republic of Indonesia, 2012.). Attitudes can be knowledge, but knowledge is accompanied by a willingness to act under knowledge This is by the statement that in determining attitudes, knowledge, plays an important role with knowledge, humans can develop what they know and can overcome the needs of survival so that it will affect a person's attitude (Sarwono, Sarlito, 2012). The development of intelligence, the growth of experience, with increasing age, can form a separate attitude towards an object. In this case, the public's knowledge and attitudes about reproductive health, especially for young people as prospective parents. Humans can develop what they know and can overcome the needs of survival so that it will affect a person's attitude (Koentjaraningrat. 2009). The development of intelligence, the growth of experience, with increasing age, can form a separate attitude towards an object. In this case, the public's knowledge and attitudes about reproductive health, especially for young people as prospective parents (Davies, T. 2009). Humans can develop what they know and can overcome the needs of survival so that it will affect a person's attitude (Natalie Hemsing, Lorraine Greaves, Nancy Poole. (2017). Green, L., Wand Kreuter MW, 2005). The development of intelligence, the growth of experience, with increasing age, can form a separate attitude towards an object. In this case, the public's knowledge and attitudes about reproductive health, especially for young people as prospective parents (Green, L., Wand Kreuter MW, 2005; Nasution. SS, at.al 2015).

\section{Conclusion}

Public knowledge, especially youths and girls in the Medan Johor sub-district, about reproductive health is generally still in the low category, which is around 55.4\%. The community's attitude was still predominantly negative about reproductive health, which was around $62.2 \%$. Village officials and health workers must be able to optimize their role in providing health education to the community. Health workers must provide reproductive health education to the community, especially families who have teenagers and productive age groups who will undergo the marriage process. The counselling program for prospective brides must be supported by village officials, health workers and involve young people directly by providing various media such as leaflets, modules, and banners on reproductive health. 


\section{Acknowledgment}

The author would like to thank Universitas Sumatera Utara and District Medan Johor Database Sources for all materials provided.

\section{Conflict of Interest}

There is no conflict of interest in this research result

\section{REFERENCES}

[1] Andrew E. Czeizel, Attila Vereczkey. (2012). An argument for the Introduction of Preconception Service as the new Infrastructure of Reproductive Health. Asian Pacific Journal of Reproduction. 1 (2) 142-146

[2] Bobak, IM, Lowdermilk, DL, \& Jensen, MD (2005). Maternity nursing. 4th ed. (Wijayarini, MA, \& Anugrah, PI: Translator). California: The CV.Mosby. (Source published 1995).

[3] Corin, SS, Arnold, J. (2006). Health Promotion in Practice. San Francisco: Jossey-Bass.

[4] Green, L., Wand Kreuter MW, (2005). Health Program Planning: An Educational and Ecological Approach. Fourth Edition, Mc Graw Hill, New York.

[5] Hamilton, PM (2001). Fundamentals of Maternity Nursing (2nd ed.). Jakarta: EGC.

[6] Humphreys, J., \& Campbell, JC (2004). Family violence and nursing practice. Philadelphia: Lippincott Williams \& Wilkins.

[7] Koentjaraningrat. (2009). Introduction to Anthropology. Jakarta: Rineka Cipta

[8] Ministry of Health of the Republic of Indonesia.PedoNman balanced nutrition. Jakarta: MOH RI; 2012.

[9] May, KA \& Mahlmeister, LR (1994). Maternal \& Neonatal Nursing Family-Centered Care. 4th ed. Philadelphia: J B Lippincott Company

[10] Nasution. SS, Badaruddin, Dasatjipta, G, Lubis. Z. (2015) Effectiveness of the Health Awareness Community Team Intervention in Improving the Maternal and Neonatal Health Status in Mandailing Natal (Madina) North Sumatra Indonesia. International Journal of Medical Science and Public Health. Vol. 4. Issue 6

[11] Notoatmodjo, Soekidjo. (2010). Health Research Methodology (Revised). Jakarta: Rineka Cipta.

[12] Nasution. SS, (2018). Nursing Care for High-Risk Pregnant Women: HIV-AIDS by Involving Communities. USU Press.

[13]. Natalie Hemsing, Lorraine Greaves, Nancy Poole. (2017). Preconception Health Care Intervention: A Scoping Review. Journal of Sexual and Reproductive Healthcare. 14 (2017) 24-32.

14] Nasution. SS, Erniyati, Hariati (2019). Effectiveness of Health Education in Increasing Knowledge and Attitude Towards Free Sex in Medan. Sudirman's Nursing Journal. Journal Homepage: www.jks.fikes.unsoed.ac.id 
[15] Notoatmodjo, S. 2007. Health Promotion \& Science Behavior. Jakarta: Rineka Cipta.

[16] Simkhada. B, Porter.M, Teijlingen. E (2010) The Role of mothers-in-law in antenatal care decision-making in Nepal: a qualitative study: Journal BMC Pregnancy and Childbirth 2010, 10:34

[17] Sarwono, Sarlito. (2012). Adolescent Psychology. Jakarta: PT. Raja Grafindo Persada. 